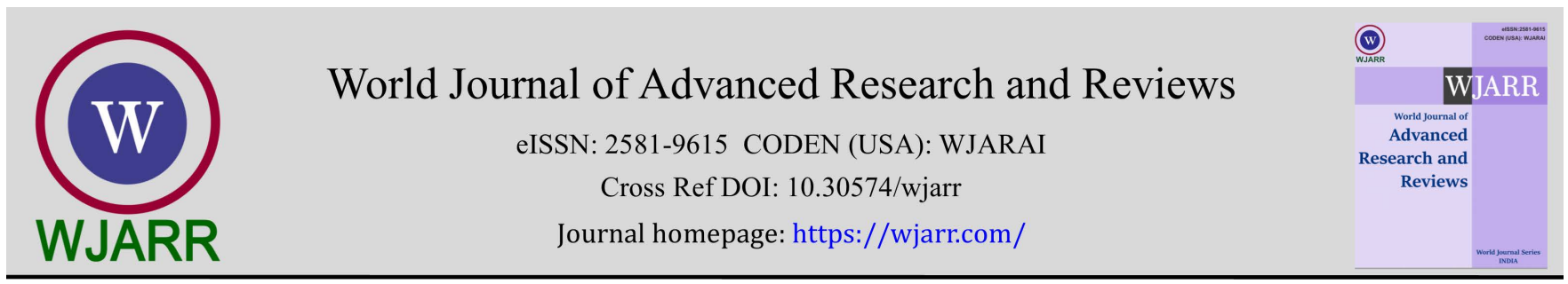

(REVIEW ARTICLE)

\title{
Impactful role of women for freedom struggle in India and their contribution
}

\author{
Dr Sumanta Bhattacharya ${ }^{1, *}$ and Bhavneet Kaur Sachdev ${ }^{2}$ \\ ${ }^{1}$ MAKAUT, Public-Foreign-Defence Policy, MPI (oxford University) ORCID ID: 0000-0003-2563-2787. \\ 2 Political Science hons (Calcutta University) Development studies, ORCID ID: 0000-0001-9156-0086.
}

World Journal of Advanced Research and Reviews, 2021, 12 (03), 124-130

Publication history: Received on 17 October 2021; revised on 03 December 2021; accepted on 05 December 2021

Article DOI: https://doi.org/10.30574/wjarr.2021.12.3.0994

\begin{abstract}
The untold, unheard and unseen facts of the struggle for an Independent India. The role of Indian women freedom fighters in the journey of freedom struggle. Everyone speaks about the prominent role played by the male freedom fighter. However, without female freedom fighters achieving Independent India would remain a dream. From being considered as second citizens, being victims of domestic violence, uneducated population, practising sati system to transforming themselves into great freedom fighter leaders has remained unknown to a lot of people. Indian women have played an impactful role in this journey from being part of the non-cooperation movement to practising saytagraha and promoting Khadi and picketing up of liquor shops. Women like Usha Mehta, Rajkumari Gupta, Aruna Asaf Ali, Rani Lakshmibai of Jhansi, Rani Gaidinliu, Amal Prabha Das, Azizam Bai, Gulan Kaur, Sarojini Naidu has played paramount role in making India free from British rules. Their participation in all the freedom struggle is significant and respectful.
\end{abstract}

Keywords: Women Freedom Fighter; Independent India; British rule; Participation; Women movement

\section{Introduction}

The untold History of India, we don't find in our history books the role played by great women in the journey of freedom struggle in India. The history is filled with the names of eminent male freedom fighters. In reality without the help of women movements and women freedom fighter the success of an Independence India would have remained a dream. When great freedom fighter was in the jail, these women groups and individual women came out and took initiative and played a paramount role. India is a country which is backed by rituals, caste, gender inequality and orthodox natural of the people. In the pre-independence era women were considered as secondary to men in short referred to as second class citizens, whose responsibility incorporated during domestic work and bearing children, there were kept inside the four walls of their home, unaware of the outside world, females where not educated and no skill development training was provided to them, During the Vedic period education was approachable for women in India which gradually lost its importance over the years. Women were victims of dowry death, domestic violence, honor killing, child marriage, open harassment of widows, opposition to widow remarriage, domination of purdah system However things changed during Gandhian period where we saw massive women participation in the freedom struggle of India which led to the modern era period. During the time of East India company rule social reformers like Raja Ram Mohan Roy, Jyotiba Phule and Ishwar Chandra Vidya Sagar faced many challenges in uplifting the status of women and ended sati system in India. Many prominent women freedom fighters like Rani Lakshmi Bhai who fought for the Independence of India. We can go back to 1817 where women participation in the struggle against freedom started when Bihma Bai Holkar who fought for its country freedom against British, Madam Bhaikaji Cama who fought for its motherland freedom the first women socialist after 1857 uprising. Women's contribution in anti-imperialist struggle is humongous. Women in India went through extreme torture hardship and exploitation to bring freedom for its people. The sacrifices made by the women in the freedom struggle is unimaginable and receives utmost importance. The role played at different events which

* Corresponding author: Dr Sumanta Bhattacharya

MAKAUT, Public-Foreign-Defence Policy, MPI (oxford University) ORCID ID: 0000-0003-2563-2787.

Copyright (c) 2021 Author (s) retain the copyright of this article. This article is published under the terms of the Creative Commons Attribution Liscense 4.0. 
incorporates The First war for Independence (1857-58), the Jalianwalabagh Massacre (1919), Non-cooperation movement launched (1920), Civil Disobedience the Dandi March (1930) and the Quit India Movement (1942). Women from al walks of life, women belonging from educated and liberal families from different caste, religion community and rural life came together to fight for their mother land freedom. However very few names are mentioned in the books and there are more than 100 women freedom fighters who participated and gave away their lives for their motherland. India being a male dominant society has spoken very less about the role played by women who deserve utmost respect and honour for their sacrifices.

\subsection{Research Methodology}

For the purpose of this exploration, I have used a amalgamation of two of the archetypical social sciences research tools application -as they are authentic and brilliant method to assemble statistics from multiple appellant in an methodical and convenient way. Question was asked to the parents and their children, survey, interviews -consisting of several interrogation which were dispersed among representative of each contender group and Qualitative analysis to congregate extensive perception of the stumbling block.

\section{Objective of the Research Paper}

The main areas of exploration in this paper incorporates

- Understand the importance of women in the freedom struggle of India

- The role played by different women groups and women movement to make India Independent.

- An in-depth study of Individual women freedom fighter who fought for our freedom against British which has remained untold.

- The sacrifice and the contribution of each women freedom fighter in the freedom struggle journey from Revolt of 1857 to Quit India Movement 1942.

\section{Literature Review}

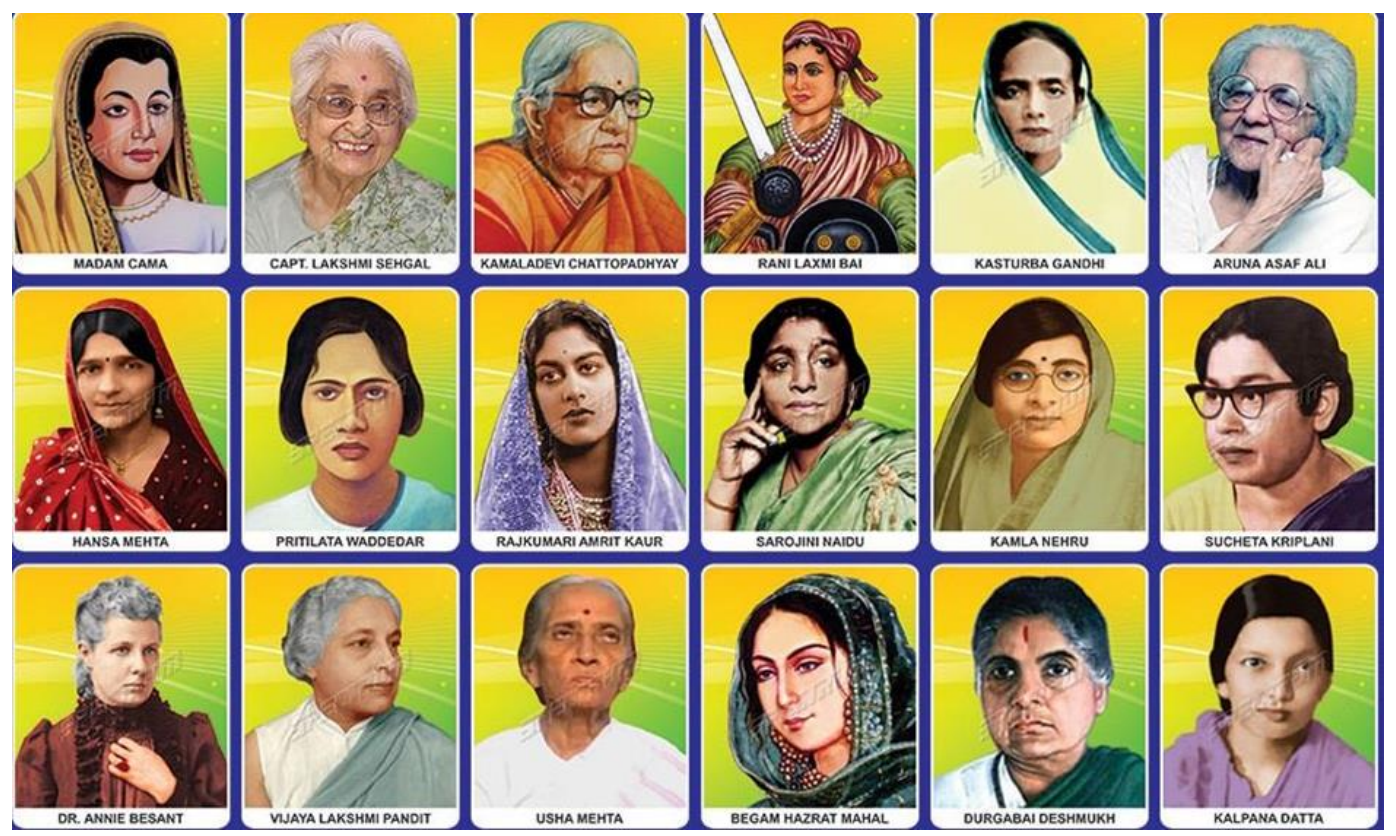

Figure 1 Women empowerment and their contribution to Freedom struggle

Women participation in the history of freedom struggle can be traced back to 1817 Bhima Bai Holkar who fought against the British Colonial Malcolm and defeated him in the guerrilla welfare. Many other women like Rani Channama of Kittur, Rani Brgam Hazrat Mahal played a prominent role and fought against the East Indian Company in the 19th century before the War of Independence of 1857, 30 years before, The First war of Independence 1857 -58 -Even though the Britishers were successful in ending the war in a year.It was a remarkable and magnificent revolt has it involved massive participation from Indian rules, women and milita. Rani Lakshmi Bhai was the first freedom fighter of the struggle for Independence India.She made people realize the value of patriotism, heroism and self-respect. She was a queen of a 
small town but the ruler of a boundless empire of glory, followed by which we have the non-cooperation launch 1920 . Gandhi ji return from South Africa and demand for self rue and non-cooperation movement called for massive participation from all walks of life including women,youth and old people where women leaders like Sarla Devi, Susheela Nair, Rajkumari Amrit Kaur, Muthulaxmi Reddy,Aruna Asaf Ali and Sucheta Kirpalani participated in the non-violent movement.Kasturba Gandhi, Kamala Nehru, Vijaya Lakshmi Pandit and Swarup Rani were involved in the National movement. The movement in Lahore was led by Lado Rani Zutshi and her daughter Manmohini Shyama and Janak.The Civil Disobedience movement and the Dandi Salt March 1930 -The women started their fight by breaking salt, forest laws and taking out Prabhat Pheries processions, picketing schools, legislative councils, colleges and clubs. Sarojini Nadiu played a prominent role in the Dandi March process and also raid upon the Dharasana Salt Works in 1930, May.Kamla Devi on the other side addressed meetings, arranged salt and picketing of foreign shops and liquor shops. Nari Satyagraha committee, Mahila Rashtriya Sangha and Ladies Picketing Board played a significant role during that period.The organization of the revolutionaries which was active in Chiitagong, Comila and Dhaka and involved the participation of young college girls. The outstanding group of women revolutionaries included of Samiti and Suniti, Kalpana Dutta, Bina Das and Presstilata Waddedar. The Quit India movement of 1942 which involved maximum women empowerment and it was a direct against the British soldiers to leave India which includes Freedom Fighters like Usha Mehta, a patriot who had set up a radio transmitter called the Voice of Freedom propagate the mantra of freedom war. Gandhi popular Do or Die, news about protest and arrest, activities by the young nationalist and other messages where spread amongst the masses by Usha Mehta and her brother till she was arrested. Women also actively participated in the swadeshi movement, Jalianwalabagh massacre and other movements for the freedom struggle in India.

\section{Findings}

\subsection{Great Women Freedom Fighters of India}

\subsubsection{Rani Lakshmibai of Jhansi (1828-1858)}

Is regarded as a fearless warrior who played a major role in the First war of Independence and fought against the British for their freedom. She is model of patriotism, self-respect, courage and perseverance. Rani Lakshmibai was a vital figure in the Indian Revolt of 1857.

\subsubsection{Sarijoni Naidu (1879-1949)}

She has been named as the Nightingale of India, noticeable poet, remarkable freedom fighter and an orator. She crusade for the Khilafat movement and the Quiz India Movement and was elected as the President of the Indian National Congress in 1925.

\subsubsection{Madam Bhikaji Cama (1861-1936)}

She has played a prominent role in the Indian struggle for freedom and also the first women to unfold the Indian Flag at the International Socialist Conference in Germany.

\subsubsection{Begum Hazrat Mahal (1820-1879)}

Also referred to as Begum of Awadh, who played an impactful role in the Revolt of 1857 she team up with Nana Saheb and Tantia Tope during the revolt and a stamp to commemorate Begum Hazrat Mahal was issued by the Government of India in 1984.

\subsubsection{Annie Besant (1847-1933)}

An Irish lady and a commanding member of the Theosophical society. She connected with the Indian National Congress and participated in the political and educational activities in India, she was the first women to be elected as the president of congress, she led the Establishment of the Indian Rule Movement in 1916, she opened a number of schools which also incorporates the Central Hindu College, High school of Banaras and started a newspaper called New India.

\subsubsection{Aruna Asaf Ali (1909-1996)}

She is recognised as the Grand Old Lady of the Independence India, an active member of the congress party, she was also engaged during the Civil Disobedience and salt saytagraha in public marches and monthly journal of the Indian National Congress named In-Qilab she was the editor of it and during the Quiz India Movement she hoisted the Indian National Congress flag in Bombay. 


\subsubsection{Usha Mehta (1920-2000)}

She is known for broadcasting the congress Radio during the Quit India Movement and was also responsible for circulating information regarding news ad arrest, protest movement and actions taken by the national youth and Gandhi slogan Do or Die.

\subsubsection{Kasturba Gandhi (1869-1944)}

Leader of the women Satyagraha and was engaged with indigo workers in the Champaran, Bihar in the No Tax Campaign and Rajkot Satyagraha.

\subsubsection{Kamala Nehru (1899-1936)}

She played a vital role in the campaign against No Tax in the United Province and was led picketing of liquor shops and foreign cloth shops and participated in the freedom struggle.

\subsubsection{Vijay Lakshmi Pandit (1990-1990)}

She was the President of the congress party, she joined the non-cooperation movement to fight for an Independent India and was arrested in 1940 and in 1942 she participated in the Quit India Movement.

Umabai Kundapur (1892-1992)

She served the nation for 50 years, leader of women's wing of Hindustani Seva Dal and creator of the Bhagini Mandal. She helped Dr Hardikar to recruit over 150 women to help in Belgaum session of the All India Congress.

\subsubsection{Uda Devi}

Was a warrior in the Revolt of 1857, she was Dalit who climbed a pipel tress and shot around 32 to 36 British soldiers and is recognised as a brave feet by British.

\subsubsection{Begum Royeka (1880-1932)}

She was creative writer and a social impact worker in Bengal, who led the foundation of a school primarily for Muslim Girls who is referred to as a Notable Muslim Feminist, through her writings she raised her voice against the challenge and fought for Bengali Muslim women.

\subsubsection{Capt Laxmi Sehgal (1914-2012)}

A great freedom fighter, the women who stood against casteism in India and fought for the freedom of India.

\subsubsection{Ammu Swaminathan (1894-1978)}

A political activist and a social worker during the Indian Independent movement and was a member of the constituent assembly. She is recognised as one of the strongest voices against the caste system in India. She was part of various cultural and social organisation and was the president of Bharat Scouts and guides and was selected as the mother of the year in 1975 and a member of Rajya Sabha.

\subsubsection{Matangiri Hazra - (1870-1942)}

She was known as Gandhi Buri, she was a prominent Indian revolutionary. She participated in the Quit India Movement, at the age of 71 she went to capture a police station during the Quit India Movement.

\subsubsection{Rani Gaidinliu (1915-1993)}

She is regarded as the most iconic freedom fighter who joined the movement at the age of 13 years, she led the Heraka movement to revival the Naga Tribal region, she started a movement against the Britishers in Cachar Hills and the Hangrum Village which threatened the British Raj which further let her go underground.

\subsubsection{Sucheta Kriplani (1908-1974)}

She was the first women chief minister who served the government of Uttar Pradesh from 1963-1967, participated in the quit India Movement and worked closely in several partition movements with Mahatma Gandhi. 


\subsubsection{Savitri Bai Phule (1831-1897)}

She is regarded as one of the early feminists who stood against the caste and gender discrimination and opposed child marriage, she led the foundation of the first women's school at Bhida Wade in Pune 1848, she recognised the untouchables and open a home to help the young widows, to transform the lives of widows and eradicate child marriage.

\subsubsection{Jhalkari Bai (1830-1890)}

She played a prominent role in the battle of Jhansi and provide the queen the opportunity to escape and took over the command in the army, she is regarded as a courageous woman and a shadow of Jhansi ki Rani, who had incredible fighting tactics which led her into Durga Dal.

\subsubsection{Janakidevi Bajaj}

She was closely associated with Mahatma Gandhi, In the year 1921 she burnt all kind of clothes being used in and out of her home which were foreign, she promoted khadi among people and she worked day and night on Charkha and spindle and gave door to door training on Charkha.

\subsubsection{Kuntala Kumari Sabat}

She was a follower of Gandhi who believed that Independence is her birth right and encouraged other women to be participate in the freedom struggle. She is the founder of Bharati Tarpovan Sangha which was built for promoting oriya literature, she was a poet and she used that as a tool in the journey of Independent India.

\subsubsection{Sarala Devi Chaudhurnai}

She used music as a weapon to invoke patriotism among the people, she was the editor of a powerful nationalist Urdu weekly, Hindustan newspaper, she also published English edition. She was highly influenced y Gandhi philosophy and dedicated her life to the National struggle.One of her motive was to empower women, she educated them and formed the Bharat Stree Mahamanda.

\subsubsection{Annupurna Maharana}

was an outstanding freedom fighter and a social reformer, she was closely connected with Mahatma Gandhi and took part in several programme for the upliftment of poor. During the Quit India Movement, she was send to prison many a times.

\subsubsection{Rajkumari Gupta}

She was closely associated with Chandrashekar Azad and supported him by carrying materials and messages to other revolutionaries, she played a paramount role in the Kakori train robbery, she supplied guns and pistols for the robbery and was connected with the Azad group in Allahabad which was later led by Bhagat Singh.

\subsubsection{Nalinibala Devi}

She was among the few women who participated in the non-cooperation and swadeshi movement in Assam. She along with Hemanta Kumari Devi and Guneswari Devi opened a training centre in Guwahati to amplify the production of khadi. which influenced a number of women which resulted in opening 500 Khadi caps for congress which was used as a weapon against British.

\subsubsection{Chandraprava Saikiani}

She was a social reformer who stood against the caste system, she allowed the entry of women to the Hajo Hayagriv Madhav temple near Guwahati. She participated in the India struggle and joined the Non-cooperation movement in 1921 and she was send to jail for engaging in civil Disobedience movement. And a rebel satyagraha.

\subsubsection{Krishnammal Jagannathan}

She was a social reform who used satyagraha as an instrument to provide land to the landless in Tamil Nadu and stood against social inequality and fought against the British for her mother land. 


\subsubsection{Yashodhara Dasappa}

She participated in various social movements including Forest Satyagraha movement, An active social worker and political activist who encouraged more and more people to participate in the Satyagraha movement, she received the Padma Bhushan the third civilian honour in 1972 by the government of India.

\subsubsection{Amrit Kaur}

She was a prominent leader in the freedom struggle who travelled across the country to circulate the message of freedom, she even joined the INC and participated in India's struggle for freedom, she also joined the Dandi march and Quit India Movement, she also went on a mission to goodwill to Bannu in 1937.

\subsubsection{Mirabehn}

She participated in the freedom movement and also joined Gandhi in the Round table conference in London 1931, she was part of the non-cooperation movement in 1931, she was arrested and detent with Gandhi, she was part of the Simla Conference and cabinet mission, the Constituent assembly and partition of India.

\subsubsection{Janaky Athi Nahappan}

She is also known as Janaky Jevar who was a remarkable commander of the Rani of Jhansi Regiment of the Indian National Army, she led the foundation of the Malayan Indian Congress under John Thivy.She was also involved in the National council of women's organisation.

\subsubsection{Nellie Sengupta}

Nellie Sengupta was a English women who fought for the Independent of India, In 1933 on the 47th annual Indian National Congress she become the President of INC. She also went to sell Khadi, door to door.

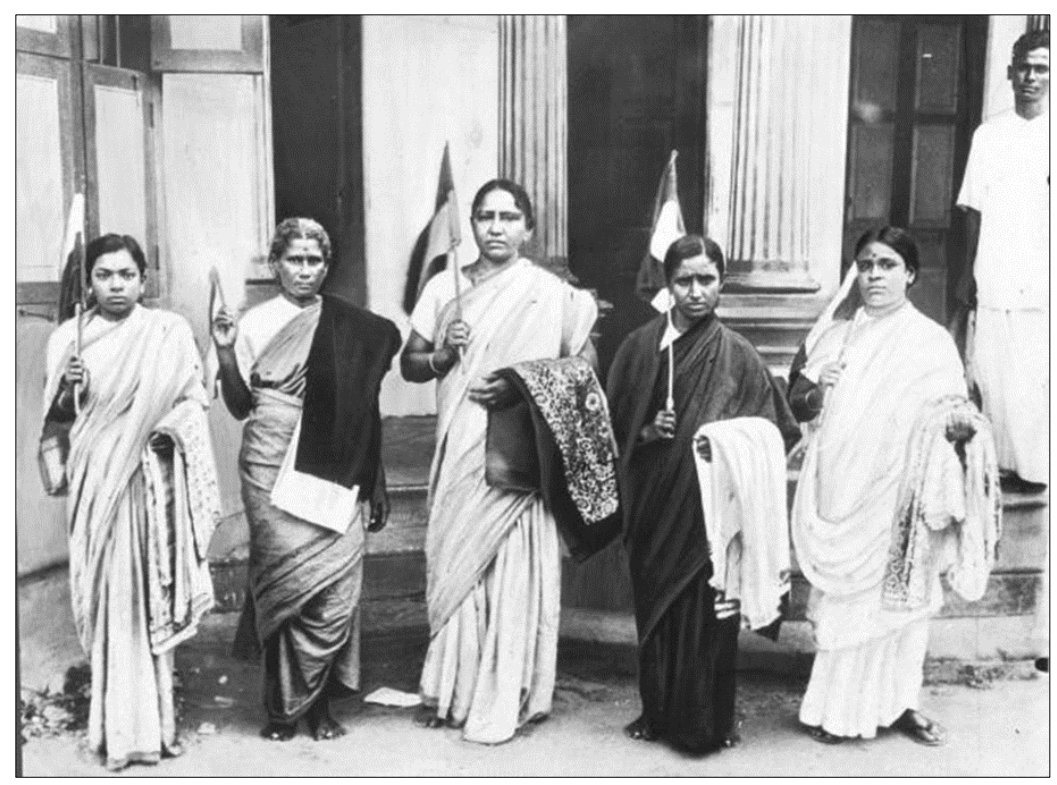

Figure 2 Women movement for Independent India, unsung Heroes

\subsubsection{Azizan Bali}

She was a warrior who fought the 1857 war, wearing a male attire and armed with pistols and also played a major role in collecting and distributing guns and pistols to the soldiers.

\subsubsection{Maa Rama Devi}

She was a freedom fighter and a social reformer who is well known for her contribution to the Bhoodan and Gramdan movement which was formed by Acharaya Vinoba Bhave.. She was highly influenced by Gandhi and participated in the non-cooperation movement and promoted khadi, Rama Devi also participated in the Civil Disobedience movement and salt satyagraha, to spread Gandhi ideas she walked barefoot across Odisha. 


\subsubsection{Kalpana Dutta}

She was known to make bombs for the revolutionist, she joined Surya Sen 's Republican Army which had carried the Chittagong Armoury raid.

The above the contribution of some of the prominent women freedom fighters whose sacrifice deserve utmost respect and the young generation should be told about them, as half of the history of freedom struggle is unknown.

\section{Conclusion}

If we talk about women freedom fighter we have more than 100 individual and crore as part of the freedom struggle journey of an Independent India,Leaders like Matati Choudhary, Subhadra Joshi, Basanti Sen, Ahslata Sen, Kanakhalat Barua, Tara Rani Srivastava, Kamaladevi Chattipadhyay, Moolmati, Durgabai Deshmuka, Rukmini Lakshmipathi. Tarkeshwari Sinha,Abadi Bano Begum, Kuntala Kumari Sabat, Indira Gandhi, Nalinibala Devi, Accamma Cherian, AV Kuttimalu Amma, Chandraprava Saikiani, Amal Prabha Das, Azizam Bai, Gulan Kaur, Bhogeshwari Phukhanai, Bhimabai Holkar, Siverine swer, Rani Velu Nachiyan, Maharani Jind Kaur, Pritilata Waddedar, Hanse Mehta,Sister Nivedita,Subhadra Kumari Chauhan and many others who gave up their life and experienced uncountable exploitation, hardship and torture in this journey. Women forms a huge population in the Indian subcontinent and opened education, employment opportunities end of caste system and pardah system to a great extent for the modern India.

\section{Compliance with ethical standards}

\section{Acknowledgments}

B.K Pattanaik: MA in economics, MA in Human resource Management, Professor at Indira Gandhi National open University.

\section{Disclosure of conflict of interest}

The authors hold no conflict of Interest.

\section{References}

[1] Dr Altaf Khan. Role of women in India's struggle for freedom, Madhav University.

[2] 70 years of Independence, These women freedom fighter laid the foundation of India's Independence. 2017. August, News Nation Bureau.

[3] Shally Rani, Role of women in Indian Freedom Movement, International Journal of Creative Research Thoughts, 2020 8(4).

[4] Raj Kumar. Women's Role in Indian National Movement.2003, ISBN - 978-8171323227.

[5] A Basu. Feminism and Nationalism in India. 1917-1947.Journal of Women's History, 1995, 7(4).

[6] Mangala Subramanian. The Indian Women's movement. Sage journal, 2004.

[7] Venkatraman V, Llitt D. Women in National Politics and Freedom Struggle, SSRN Electronic Journal. 2017; 12 (12).

\section{Author's Short Biography}

Dr. Sumanta Bhattacharya is a Research Scholar at MAKAUT and a Public-Defence-
Foreign Policy Analyst. He has 180 research papers, 27 Patents and 27 Book chapters, holds
the record for maximum number of degree courses, have won International and national
awards for his excellences in Education and Policy Making.

